\title{
SMART HYDRO-ENERGY HYBRID SYSTEM POTENTIAL IN CROATIA- BEDNJA RIVER CASE STUDY
}

Professional paper

\section{Bojan Đurin}

(Received: 11 September 2019; accepted: 5 March 2020)

University North, Department of Civil Engineering, Assistant Professor, PhD

Corresponding author: bdjurin@unin.hr

Nikola Kranjčić

University of Zagreb, Faculty of Geotechnical Engineering, Assistant, $\mathrm{PhD}$

Anamarija Muhar

Building Itd Ivanec, Master of Environmental Engineering

\begin{abstract}
The smart hydro-energy hybrid system comprises a small hydroelectric power plant and a solar photovoltaic power plant as a part of energy input for the realization of smart cities. This paper introduces the critical period method (CPM), which can be used for system sizing. According to this method, if the total energy production is lower than the energy demand, a critical period should be defined based on the largest difference between demand and production. The period (day) in which that difference appears is called the critical period. If the energy demand during this period is satisfied, the demand on the remaining days of the year is also satisfied. Any possible breaks in energy production, caused by a reduction in the expected river-flow rates or insolation (in the case of cloudiness), will be reduced to a minimum. The use of such a hybrid system guarantees the production of electricity throughout the year. Such a hybrid system could facilitate the realization of a smart city and help achieve energy stability and security. Despite Croatia having great potential in terms of solar energy use and the large number of available watercourses, such a hybrid system has never been realized. In particular, CPM has not been applied previously anywhere in the world.
\end{abstract}

Keywords: hybrid energy system; hydroelectric power plant; solar photovoltaic power plant; critical period method; smart city 


\section{INTRODUCTION}

Hybrid systems comprising a small hydroelectric (HE) power plant and a solar photovoltaic (PV) power plant are a well-known technology for the production of electric energy. Such systems do not exist in Croatia despite the country's hydro and solar potentials. The natural HE potential in Croatia is 4119 MW. Furthermore, the potential of centralized PV power plants is $5303 \mathrm{MW}$, while the technical potential of an solar photovoltaic system on buildings by 2050, considering new constructions by that year, is estimated at around 2718 MW [1]. The comparison of these potentials with the European standards or those of other countries is unreasonable because of the use of new technologies and energy systems that are not yet known or built in Croatia. Nevertheless, it should be noted that more than $21.8 \mathrm{GW}$ of renewable HE capacity was put into operation in 2018 throughout the world [2]. A very promising fact is that the world solar PV capacity has been estimated to increase significantly from 593.9 GW in 2019 to 1,582.9 GW in 2030 [3]. The installed hydropower capacity in Europe for 2018 was 251,707 MW [4]. [5] forecasted that the newly installed solar PV capacity in Europe will exceed 77.2 GW in the next five years (i.e., by year 2024).

Currently, the requirements of energy systems include increased efficiency of energy production, reduction of greenhouse-gas emissions, and usage of renewable energy systems. All these factors must correlate to the realization of sustainable energy as well as hydraulic balance.

The contribution of this study is the introduction of the concept of the smart HE hybrid system (SHEHS), which is a combination of small HE and PV power plants. In addition, this study presents the application of an innovative sizing procedure called the critical period method (CPM). Although CPM has already been presented and explained in previous studies [6,7], the focus was only on the sizing of the PV power plant for water pumping. In this study, the CPM was applied to renewable hybrid energy systems, which use hydro and solar energies. Moreover, a real case study is provided to demonstrate the application of the CPM at two locations: Bednja (which is a small local river in Lepoglava) in Croatia and Ludbreg.

The installation of micro HE power plants, which have an installed power lower that $100 \mathrm{~kW}$, is a very promising approach in small local rivers as it satisfies the economic, environmental, and social demands. In this study, a typical torrential river in Croatia, Bednja, was analyzed. River Bednja has an average flow of about $1 \mathrm{~m}^{3} / \mathrm{s}$ with an average depth of about $\leq 1 \mathrm{~m}$ [8]. A PV power plant could very easily be built at any location close to the location of a HE power plant. Panels can possibly be placed on a canopy that will be stretched along the promenade, parallel to the course of river Bednja. In accordance with the mentioned facts, SHEHS can be said to fit the concept of a "smart city." The inclusion of renewable-energy sources into the concept of "smart city" has already been approved and justified by $[9,10]$, and many others. Hydro-power and solar PV energies can be applied to smart cities [11,12].

Renewable hybrid-energy systems, which consist of hydro and solar PV power plants, are well known throughout the world. For example, the world's first hybrid HE and floating PV system is installed at the Alto Rabagão Dam in Montelegre, Portugal, with a power of $220 \mathrm{kWp}$ [13]. Further, a solar PV-hydro hybrid system with a total power of $1600 \mathrm{MWp}$ is installed at Longyangxia on Yellow river in China [14]. Taratak in Indonesia houses the PV-microhydro system with the range of 48-71.1 kWp [15]. For remote villages in Cameroon, a hybrid system with power of $8.3 \mathrm{kWp}$ has been built [16].

\section{HYDROLOGY AND SOLAR POTENTIAL}

The hydropower potential of a particular water course or river is determined by analyzing its flow. Flow represents one of the basic types of hydrological data, and a graph showing flow over a given period is called a hydrogram. A flow-duration curve shows the percentage of time or number of days in a year during which the water level is ranked according to the size or availability of water quantities with respect to the duration. Experts recommend the use of the average daily flow rate of 250 days and longer for the sizing of hydropower plants. In fact, the duration could be selected after a cost-benefit analysis. By averaging the flow over a 10 -year period, the mean value of the mean daily flow can be obtained.

The output power of the HE power plant, $P_{H E}[\mathrm{~W}]$, is defined as follows [17]:

$P_{H E}=\rho \times g \times Q \times H \times \eta_{H E}$ 
where $\rho$ is the water density $\left[\mathrm{kg} / \mathrm{m}^{3}\right], g$ is the acceleration of the gravitational force, $\left[\mathrm{m} / \mathrm{s}^{2}\right], Q$ is the installed flow $\left[\mathrm{m}^{3} / \mathrm{s}\right], H$ is the net flow [m], and $\eta_{H E}$ is the efficiency of the HE power plant [\%]. The production of electric energy, $E_{H E}[\mathrm{kWh}]$ from the HE power plant is equivalent to:

$E_{H E}=P_{H E} \times T$

where $T$ is the analyzed time, which is usually one day or year (but could include any other time amount). In other words, the energy production is usually expressed on a daily or yearly basis.

When determining the solar potential of a particular location, the intensity and duration of the solar radiation must be known. PVGIS (PVGIS, 2019) is a free online tool for estimating the production of solar PV power at any location. By entering the coordinates of the desired location in PVGIS and selecting the required output results, the annual solar-power output production and the optimum angle and inclination of solar PV panels can be obtained. In addition to the average daily value of the insolation for a period of one year, the monthly value will also be obtained. This is because the procedure for sizing a PV power system typically uses monthly averaged values $[18,19]$.

The average power of the solar PV system, $P_{S}[\mathrm{~W}]$, can be calculated by [20]:

$P_{S}=A \times \eta_{S} \times 1000$

where $A$ is the area of the PV panels [ $\left.\mathrm{m}^{2}\right], \eta_{s}$ is the efficiency of the PV system. The daily production of electric energy, $E_{S}[\mathrm{kWh}]$, from a PV power plant is calculated as:

$E_{S}=I_{S} \times A \times \eta_{S}$

where $I_{S}$ is the daily intensity of the insolation $\left[\mathrm{Wh} / \mathrm{m}^{2} /\right.$ day]. The energy production could also be calculated for any analyzed time.

\section{CPM}

It is necessary to consider the period of the year in which a small hydro power plant cannot produce the required energy but the energy production can be satisfied via the solar PV system. In other words, during the summer period when the river-water levels are usually low, the flow does not have enough power to produce energy. During this period, solar energy can replenish the energy of the micro hydro power plants. Therefore, a constant amount of electricity could be generated throughout the year. Owing to the fluctuation in the flow and strength of solar radiation as well as the lack of conformity with the estimated need for electricity, the energy needs on certain days may not be met precisely because of insufficient power generation. In other words, variability of water flow and the interruptions in the solar-radiation intensity, such as lack of precipitation, cloudiness, and period of time in which the solar radiation is small, negatively affect the energy production.

Such problems can be solved by using the innovative sizing methodology, CPM, as shown in Figure 1. 


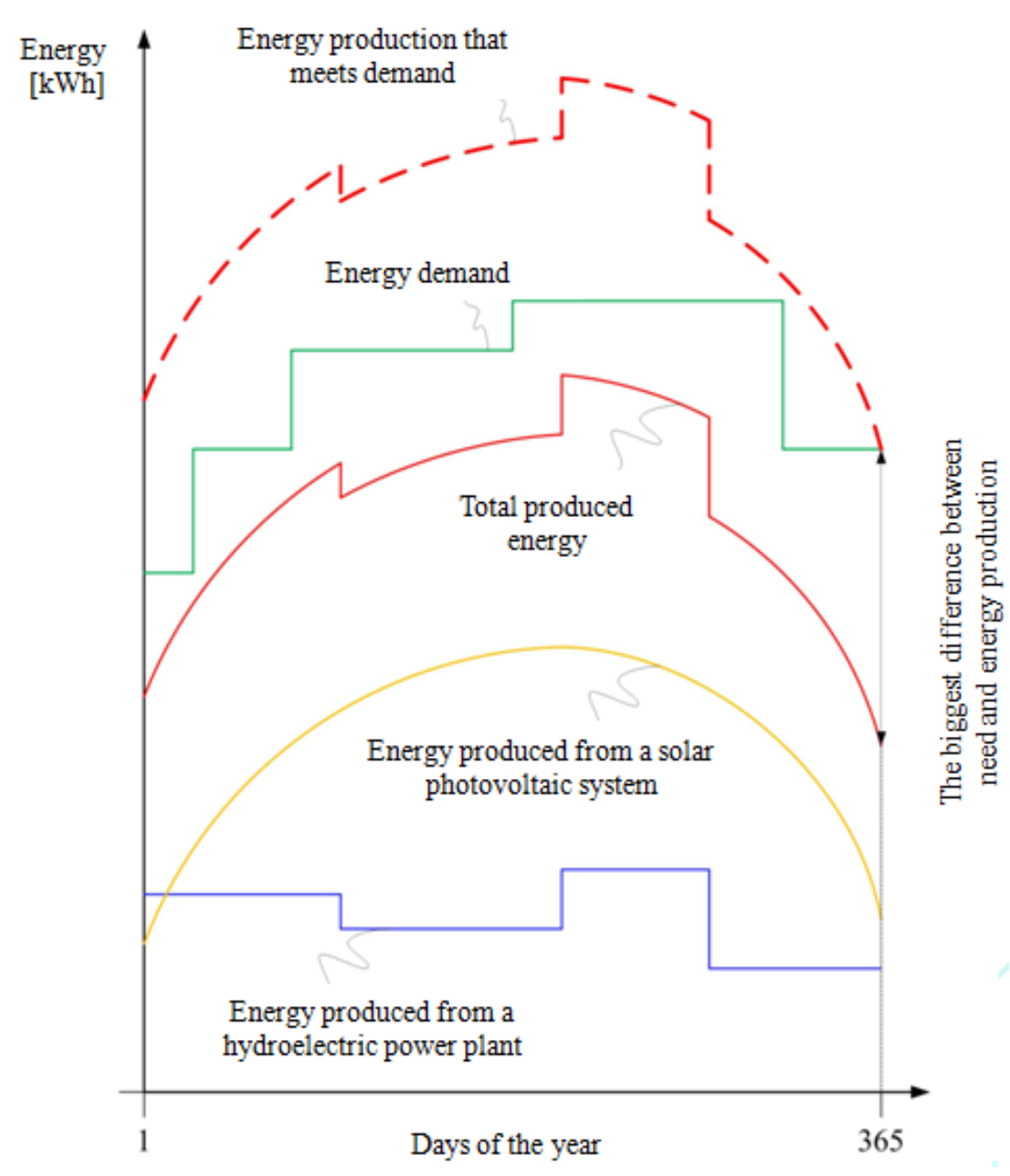

Figure 1 Concept of the critical period method

This methodology is an extension of the existing technique used to size solar PV water pumping systems at a settlement, presented by [6]. The same technique was applied for the irrigation of a football field by [21]. In these studies, only one source of electric energy, i.e., solar PV energy was used, and the analysis was conducted in terms of the energy demand for water-supply systems and energy production from the PV system. The proposed CPM considers the hydro energy as the new energy source along with the PV energy.

The SHEHS produces energy from two separate systems, i.e., small hydropower plants and a solar PV system, and their joint functioning produces the final energy of the hybrid system. If the total produced energy is smaller than the energy demand, the energy need is not satisfied. The period defined by the greatest difference between the energy demand and energy production is called the critical period. If this period (day) is satisfied, all the remaining days of the year can also be satisfied. Note that any possible breaks in the energy production caused by a reduction in the expected flow rates or sunlight (cloudiness) will be reduced to the minimum owing to the compensation of energy from the other source.

To meet the energy demands, the power of the hybrid system must be increased with respect to the critical period. Given the stochastic characteristics, i.e., flow instability, especially in rivers, increasing the power of the solar PV system than that of the small power plants is technologically simpler.

\section{CASE STUDY}

River Bednja, which flows through the northwest part of Croatia (Figure 2), was selected for a case study owing to its size and potential for energy production as well as its proximity and accessibility compared with other rivers. Its flow and depth were measured constantly through five hydrologic measurement stations, among which Lepoglava 
is the most upstream station, while Ludbreg is the most downstream station. The characteristics of River Bednja are its buoyant (variable) flow, increased flow during larger precipitation periods, and possibility of drastic reduction in the flow during summers.

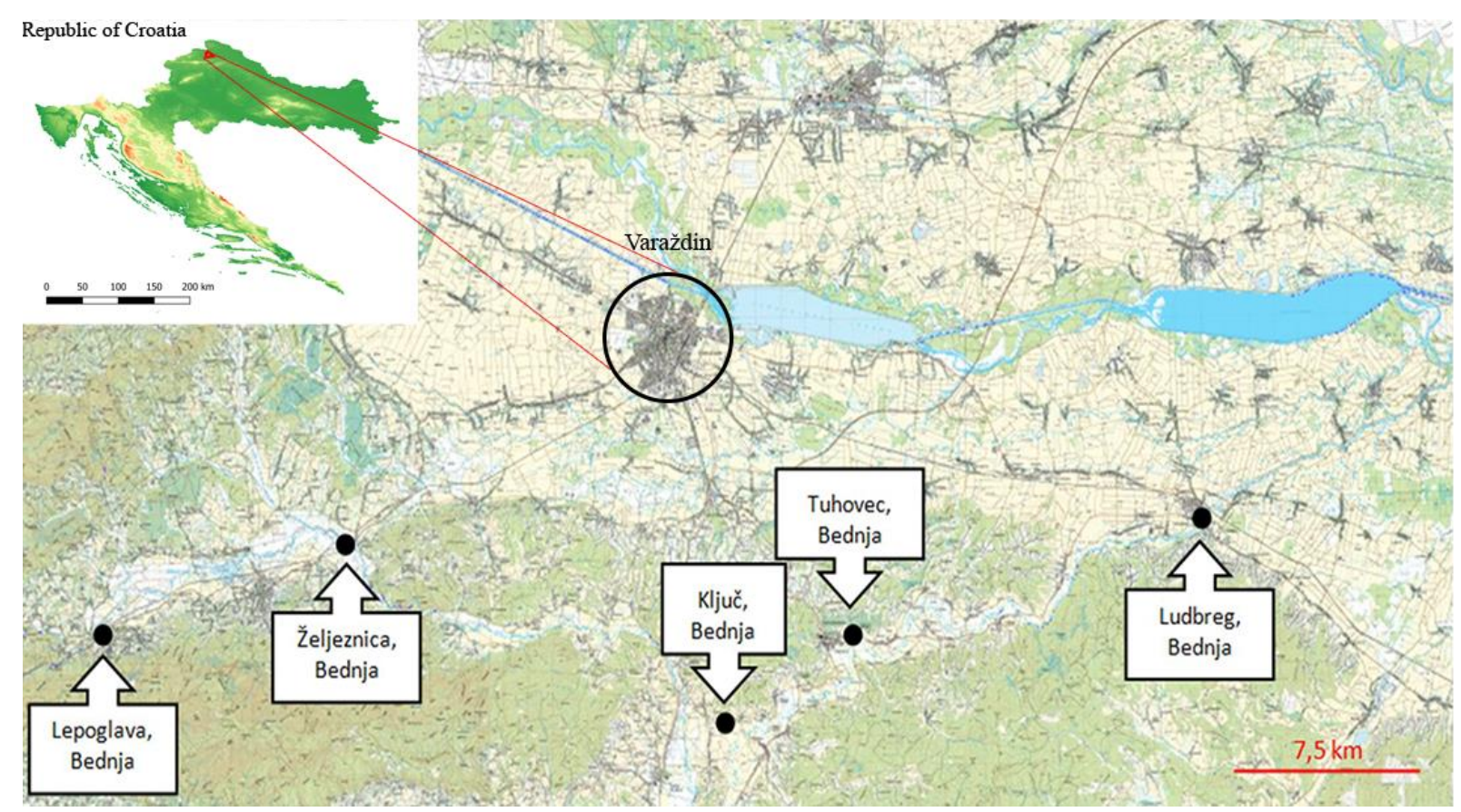

Figure 2 Locations of hydrologic measurement stations on River Bednja (modified from [22])

Figures 3 and 4 present the hydrologic characteristics, i.e., hydrograms of River Bednja for 10 years (2008-2017) obtained from the hydrological stations of Lepoglava and Ludbreg, respectively. The Lepoglava station recorded the maximum flow value of $44.7 \mathrm{~m}^{3} / \mathrm{s}$ in 2013 and the minimum flow of $0.047 \mathrm{~m} \mathrm{~m}^{3} / \mathrm{s}$ in 2017 . Further, the maximum flow value for the Ludbreg station was $113 \mathrm{~m}^{3} / \mathrm{s}$ in 2013 and the minimum value of $0.914 \mathrm{~m}^{3} / \mathrm{s}$ was recorded in 2012. 


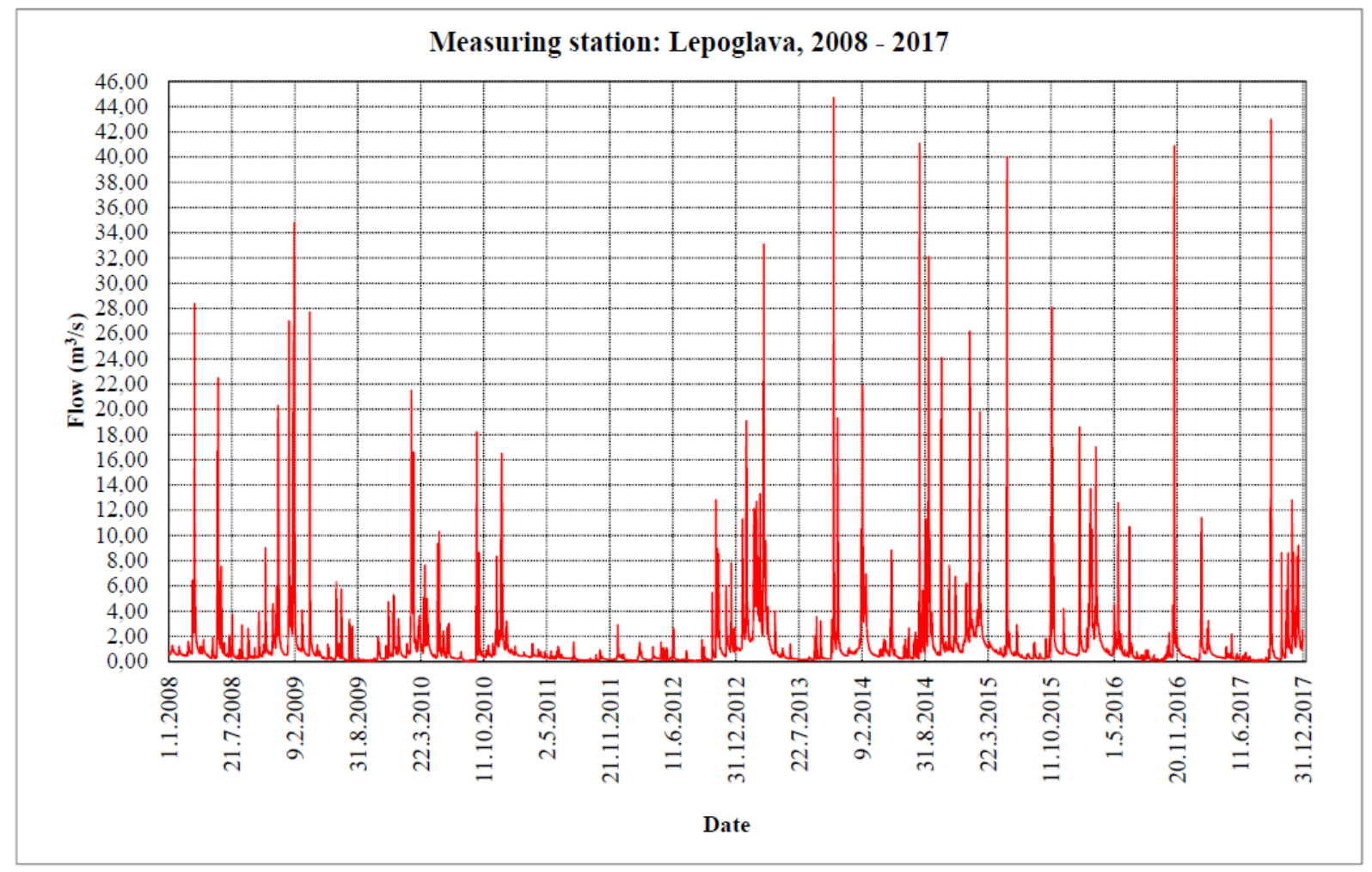

Figure 3 Hydrogram of river Bednja measured by station Lepoglava [8]

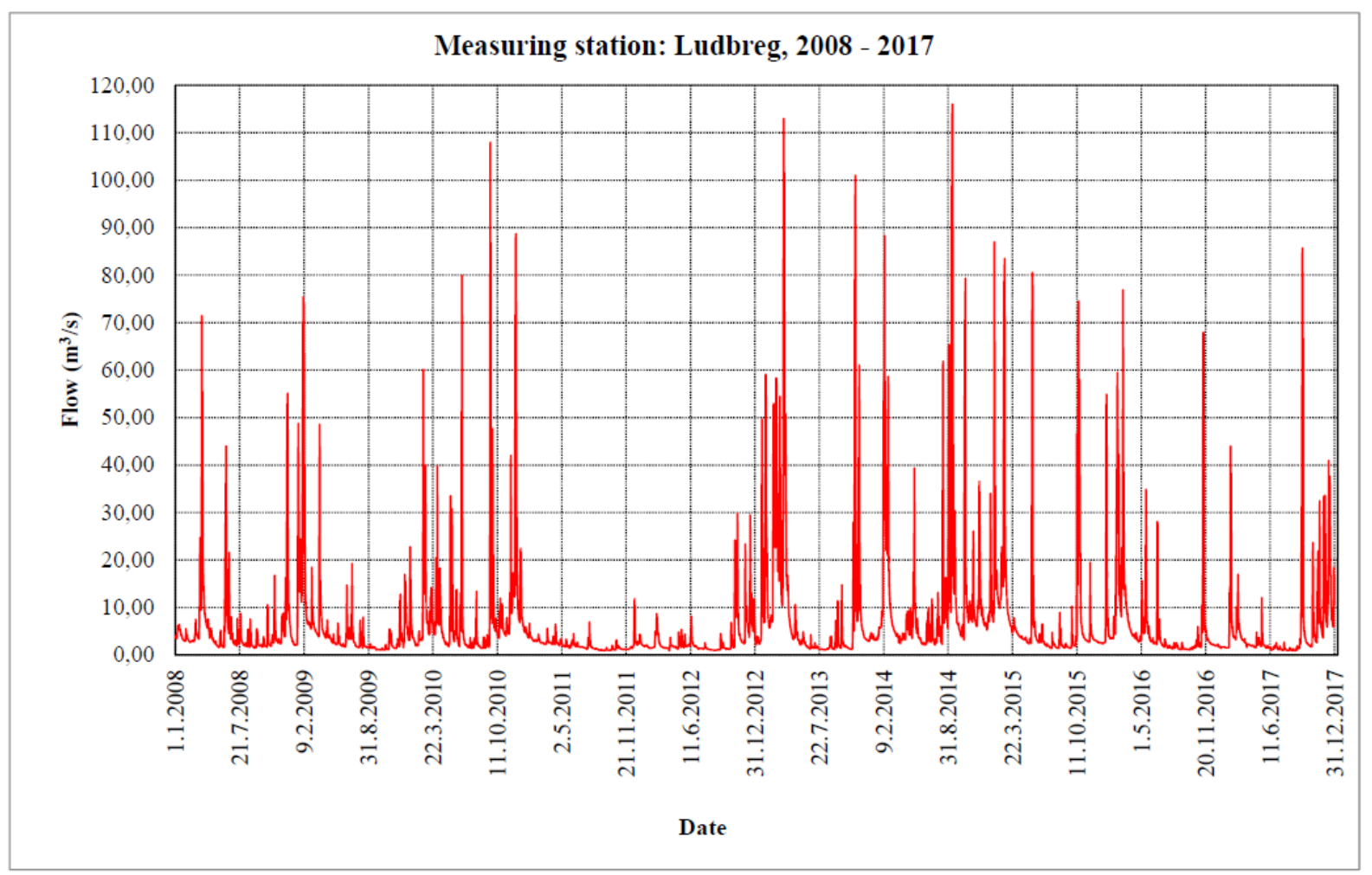

Figure 4 Hydrogram of river Bednja measured at the Ludbreg station [8] 
The flow amounts for Ludbreg are larger than those for Lepoglava owing to the influents from all water courses and channels, which flow at downstream points into Bednja. Figures 5-8 illustrate duration curves of flow and depth for the year 2017 for Lepoglava and Ludbreg. The common hydrological analysis of the flow duration is based on the average of the duration curves for the observed period, i.e., usually $\geq 10$ years. Therefore, this paper presents only the example of the last analyzed year, i.e., 2017.

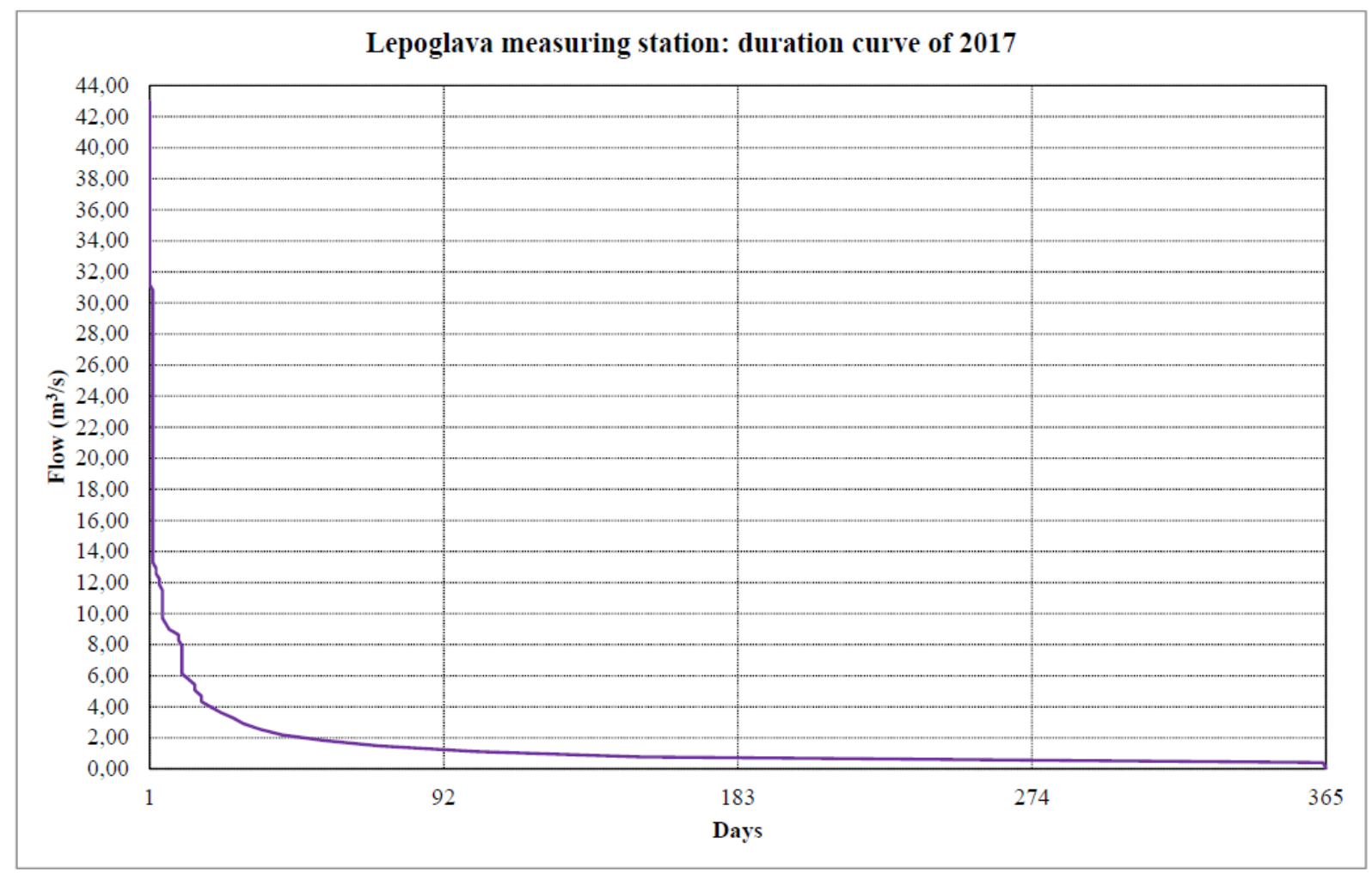

Figure 5 Duration curve with respect to flow of river Bednja measured at the Lepoglava station for the year 2017 
Smart hydro-energy hybrid system potential in Croatia—Bednja River case study

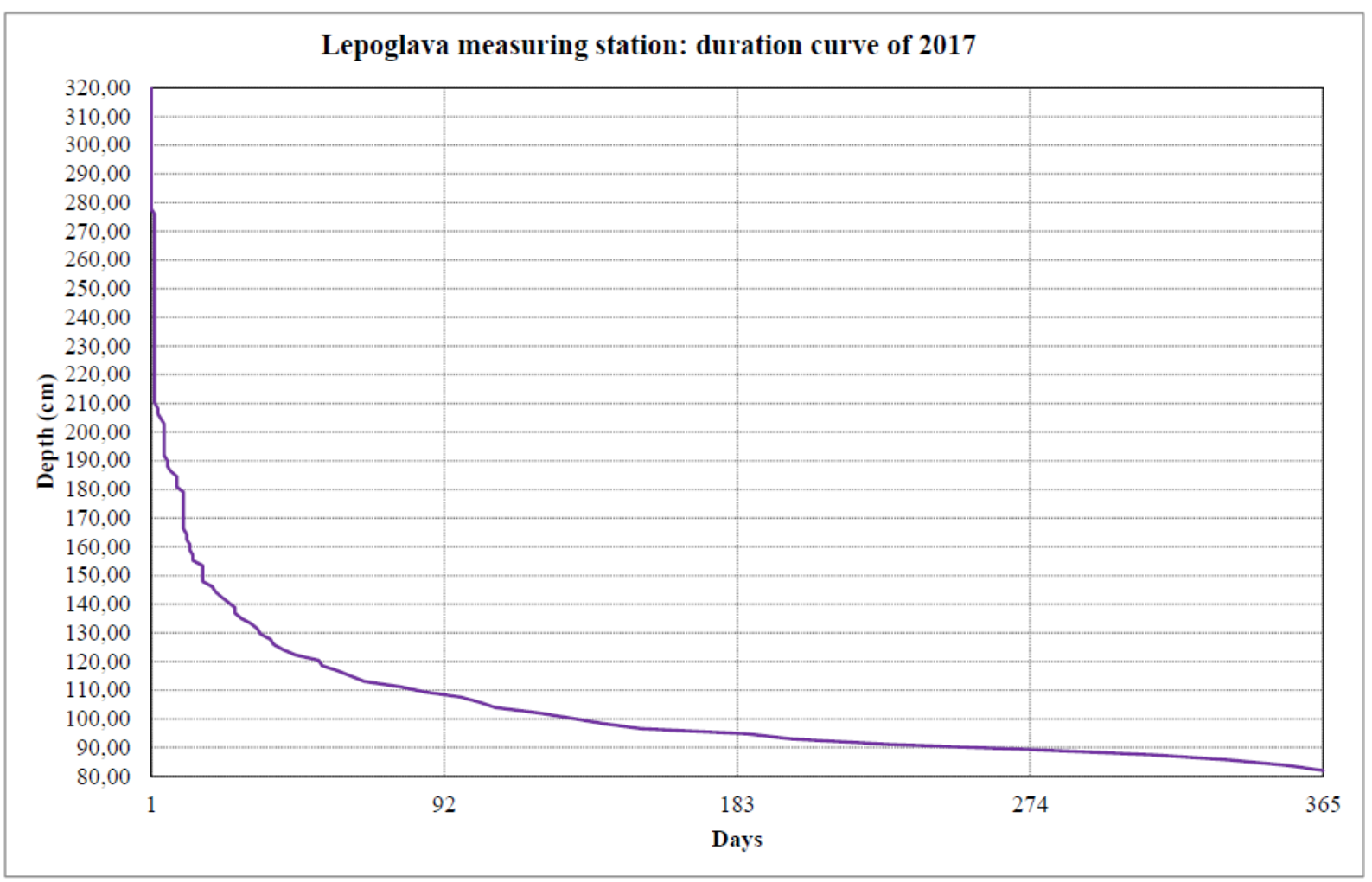

Figure 6 Duration curve with respect to the depth for river Bednja measured at the Lepoglava station for year 2017

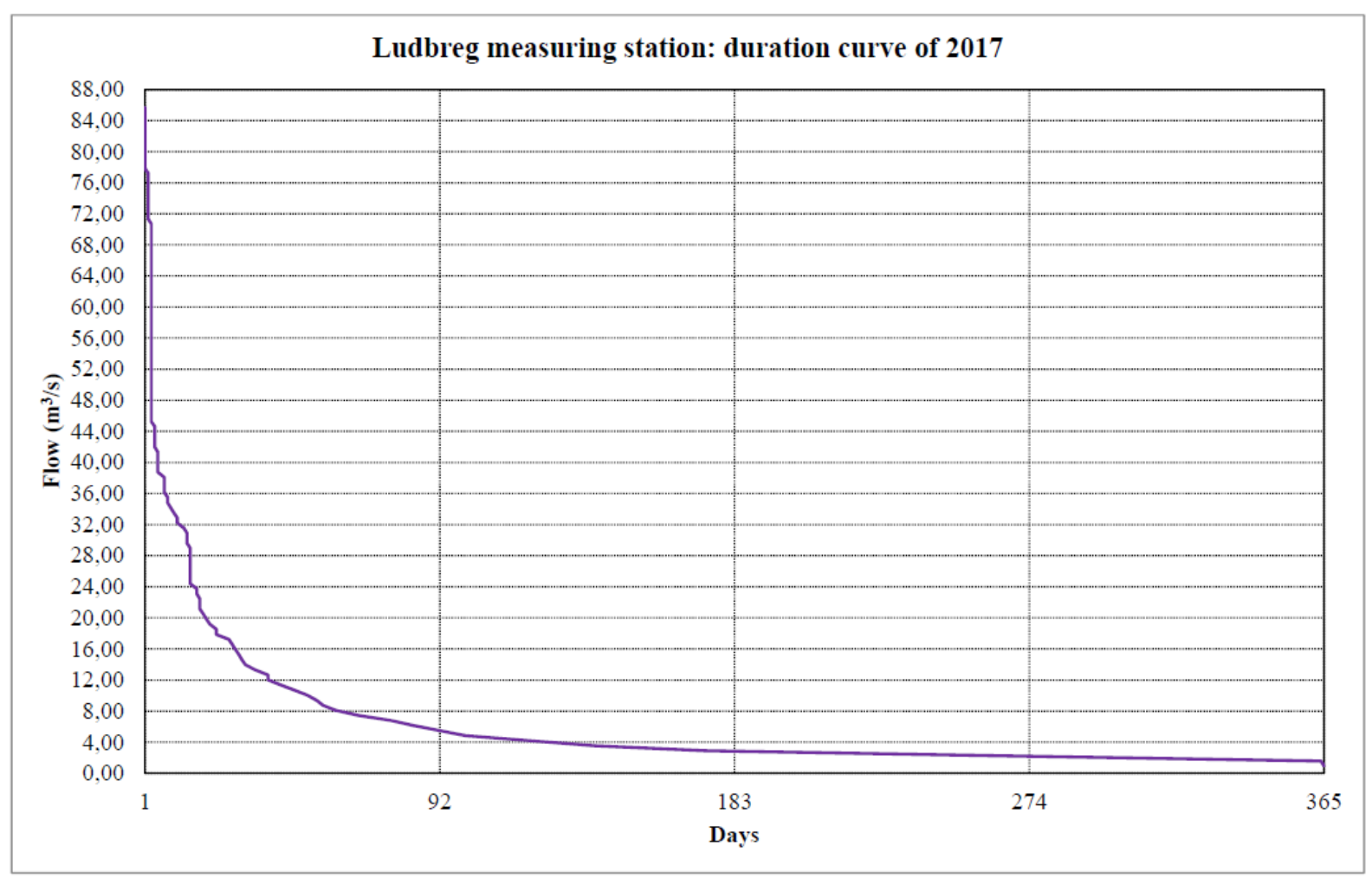

Figure 7 Duration curve with respect to the flow for river Bednja measured at the Ludbreg station for year 2017

Đurin, B, Kranjčić, N, Muhar, A 


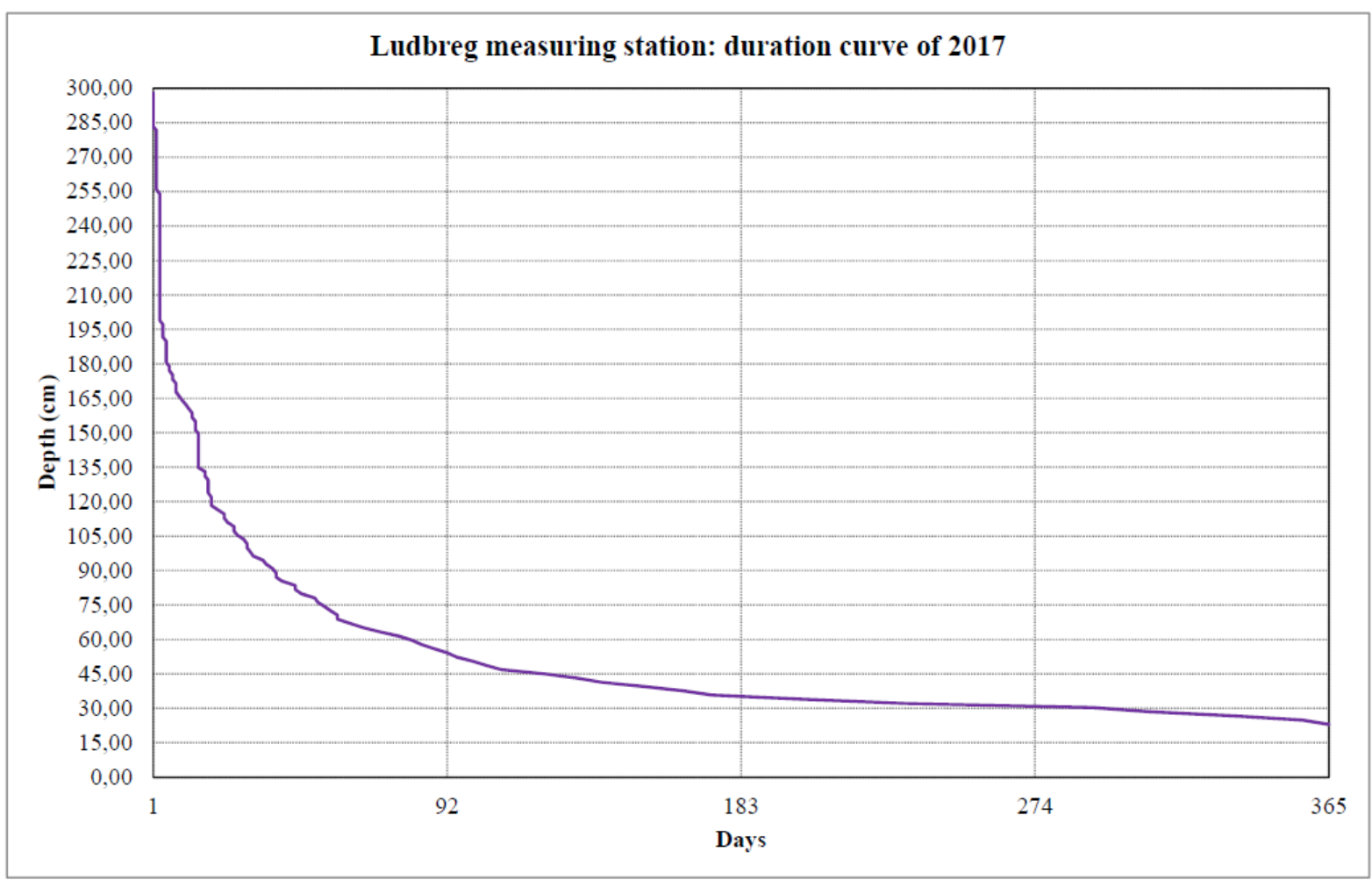

Figure 8 Duration curve with respect to depth of river Bednja measured at Ludbreg station for year 2017

By entering the coordinates in the PVGIS for Ludbreg (E 46 $\left.15^{\prime} 12^{\prime \prime}, N 16^{\circ} 36^{\prime} 56^{\prime \prime}\right)$ and Lepoglava (E 46 $122^{\prime 2} 27^{\prime \prime}, N$ $\left.16^{\circ} 02^{\prime} 36^{\prime \prime}\right)$, the intensity of the insolation was obtained, as shown in Figure 9.

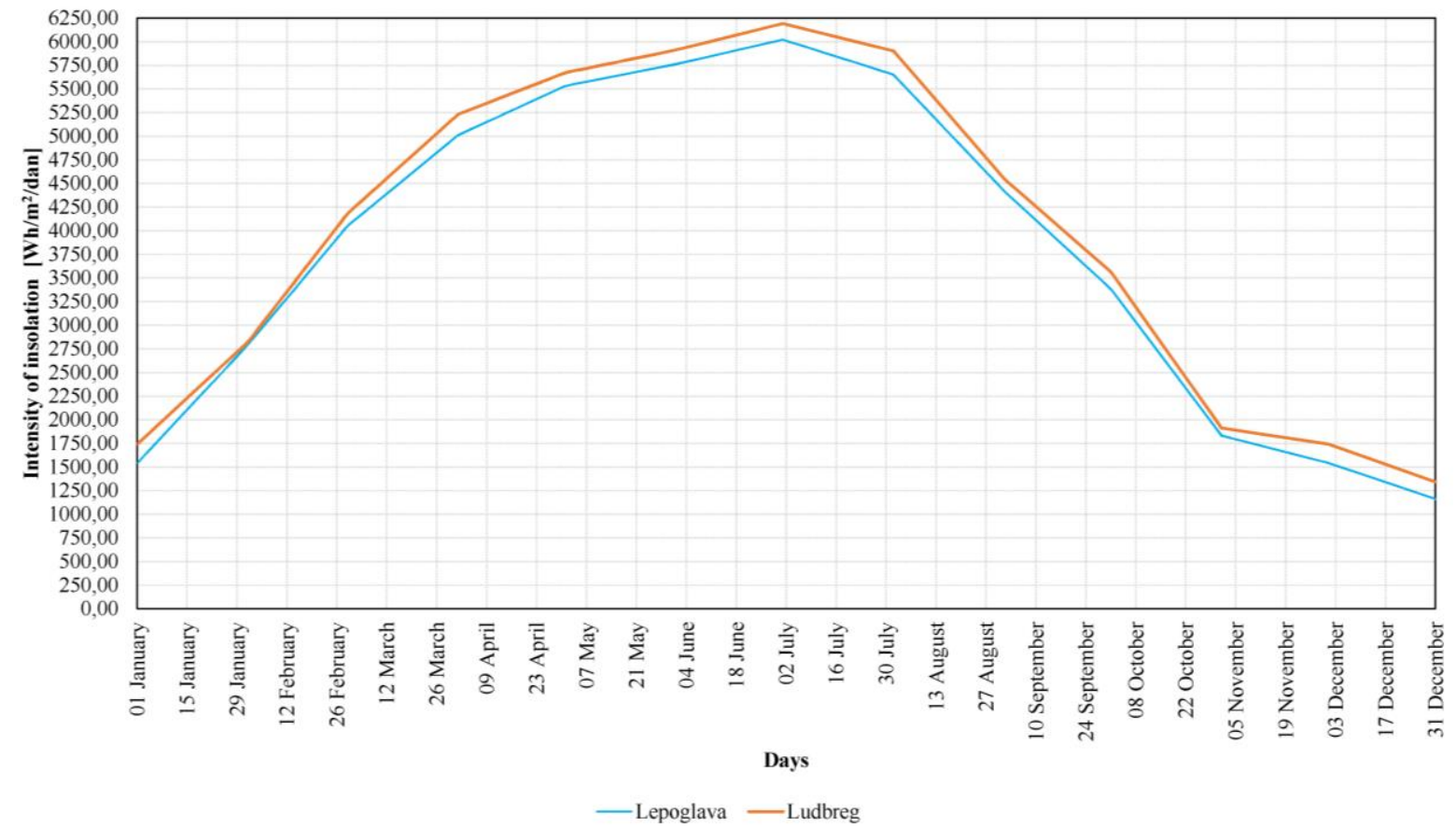

Figure 9 Global intensity of insolation under optimum inclination angle $\left(35^{\circ}\right.$ for Ludbreg and $34^{\circ}$ for Lepoglava) [23] 


\section{RESULTS AND DISCUSSION}

The average flow rates for 250 days were calculated as 3.16 and $0.60 \mathrm{~m}^{3} / \mathrm{s}$ at Ludbreg and Lepoglava, respectively. By substituting these values in equation (1), the power of each small hydro power plant was calculated by adopting the recommended average values for the turbine efficiency of $80 \%$ and determining a net height drop of $1.4 \mathrm{~m}$ as recommended by Turbiwatt (2019). As such, powers of 28.6 and $6.54 \mathrm{~kW}$ were calculated at Ludbreg and Lepoglava, respectively, thus proving the concept of a micro HE power plant. According to equation (2), the yearly energy production was $39,240 \mathrm{kWh}$ for Lepoglava and 171,600 kWh for Ludbreg. Regarding the size of the hydro power plant, it should be emphasized that the surplus water flows out of the input part of the turbine through the spillway on the entrance.

As both locations have plenty of unused space (Figure 10 left-Ludbreg; Figure 10 right-Lepoglava), the solar PV panels will occupy a strip of the river width in addition to $1 \mathrm{~m}$ on each side and $2 \mathrm{~m}$ in the direction of the river, above the hydro power plant.
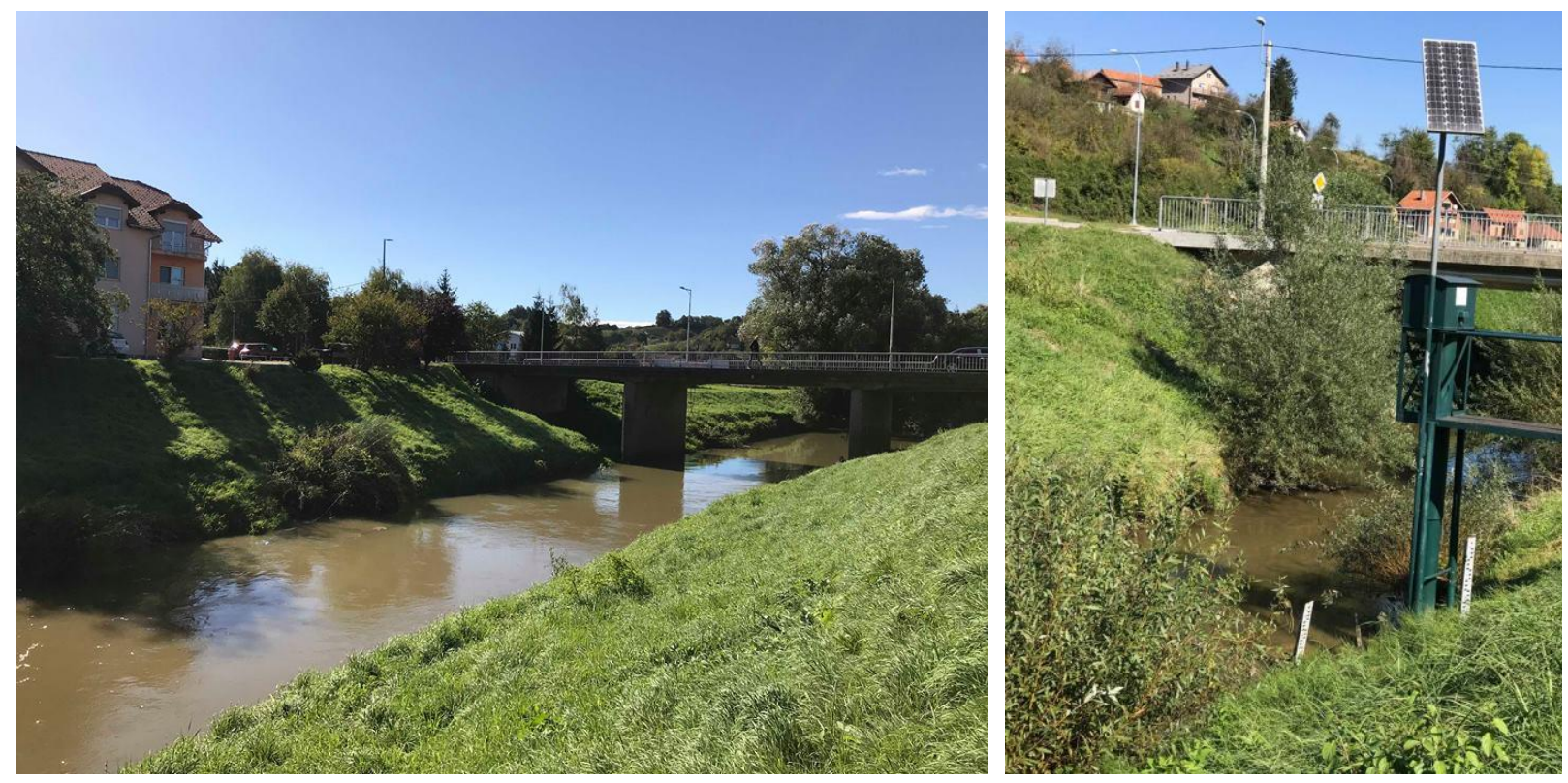

Figure 10 Location of the power plants at Ludbreg (left) and Lepoglava (right)

At Lepoglava, the calculated area is $45.2 \mathrm{~m}^{2}(20.6 \mathrm{~m}+1 \mathrm{~m}$ on each side $\times 2 \mathrm{~m}$ in the direction of the river, which is $22.6 \mathrm{~m} \times 2 \mathrm{~m})$. At Ludbreg, the calculated area is $98.4 \mathrm{~m}^{2}(47.2 \mathrm{~m}+1 \mathrm{~m}$ on each side $\times 2 \mathrm{~m}$ in the direction of the river, which is $49.2 \mathrm{~m} \times 2 \mathrm{~m}$ ). Further, the panels were located either parallel to the river course, within the river bank, or at some closer location. The PV panels were required to be set at an optimum angle with respect to the maximum energy exploitation. The optimum angle was determined using PVGIS; it was $35^{\circ}$ and $34^{\circ}$ for Ludbreg and Lepoglava, respectively. The angle must be oriented toward the south, with the accepted value of efficiency at $15 \%$ (according to literature and expert recommendation; [24]). Using equation (3), the power thus obtained for both PV power plants was $30 \mathrm{~kW}$. Using equation (4) and input data, the yearly produced energy was 13,019 and 29,467 kWh for Lepoglava and Ludbreg, respectively.

The total yearly energy production at Lepoglava and Ludbreg was 52,259 and 201,067 kWh, respectively. Such difference is due to larger flow and river width at Ludbreg. Figure 11 shows the possible graphical design of the proposed SHEHS. 


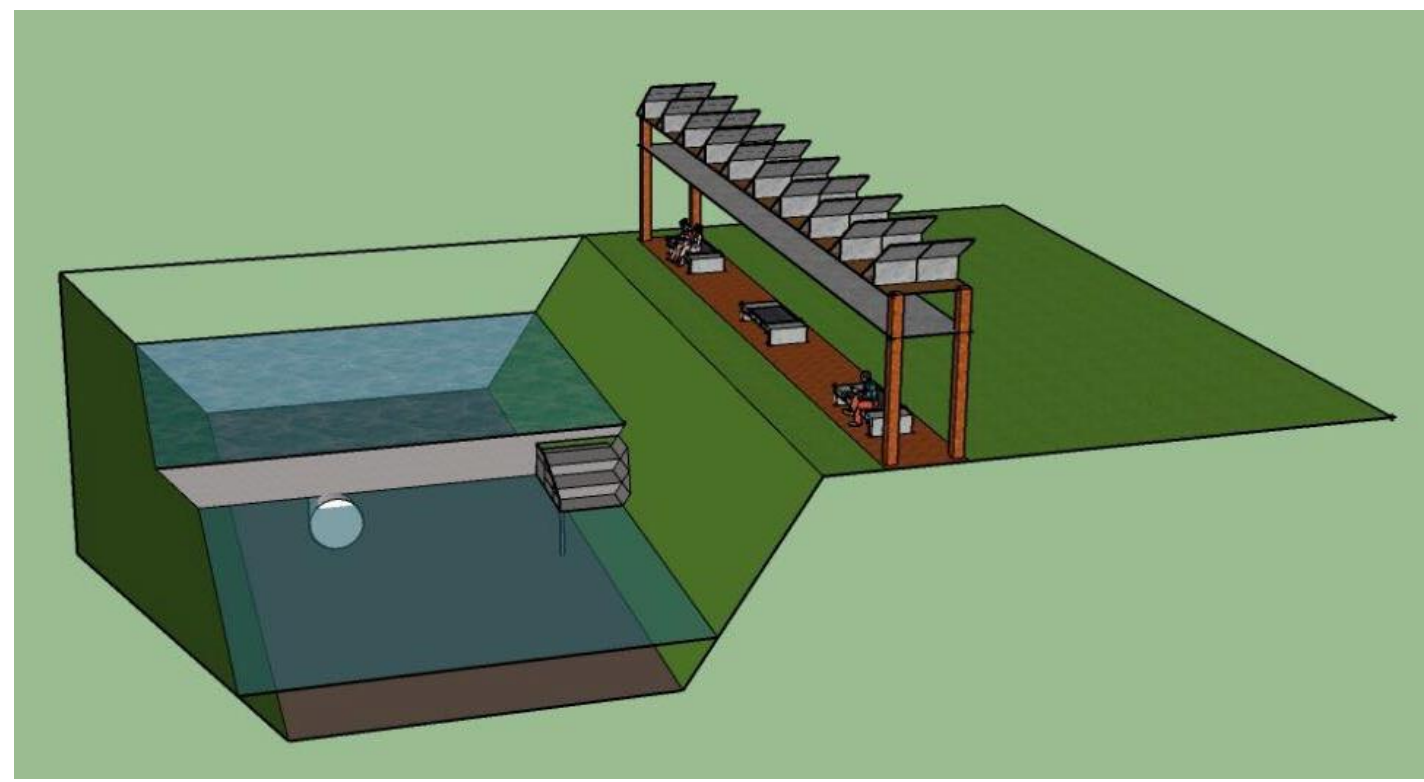

Figure 11 Possible graphical design of the smart hydro-energy hybrid system

\section{CONCLUSION}

This paper presented a very promising solution for the production of electric energy at a small scale in rural settlements. Because of the aim and scope of this paper as well as the limitation of manuscript length, the presented research and calculations were oriented to the introduction of the sustainable energy and hydraulic balance by using a renewable hybrid energy system. In addition, the paper presented the concept for realizing the mentioned sustainability. In the future, the authors would extend the knowledge gained from this study to determine the size of the mentioned hybrid system by using the CPM concept.

The proposed SHEHS distributes the produced energy to the existing power grid and achieves the energy sustainability of the city. The SHEHS does not produce greenhouse gases. Notably, such a hybrid system, which would be sized using the CPM, has not yet been built anywhere in the world. The proposed SHEHS model has the potential of being employed at various locations with a water course based on natural conditions. By using the proposed method, and ensuring the demand for electricity generation, electricity production could be guaranteed according to the estimated requirements.

\section{References}

[1] Energetski institut Hrvoje Požar 2018: Analize i podloge za izradu energetske strategije Republike Hrvatske.

[2] Henley, W. 2019: Hydropower Status Report Available online: https://www.hydropower.org/status2019 (accessed on Dec 29, 2019).

[3] GlobalData Solar Photovoltaic (PV) Market, Update 2019: Global Market Size, Market Share, Average Price, Regulations, and Key Country Analysis to 2030.

[4] Association, I. hydropower Hydropower capacity Europe Available online: https://www.hydropower.org/country-profiles/europe Accessed 29 Dec 2019

[5] Wood, L. 2019: Europe Solar Photovoltaic (PV) Power Market Outlook Report 2018-2027 ResearchAndMarkets.com.

[6] Đurin, B.; Margeta, J. 2014 Analysis of the Possible Use of Solar Photovoltaic Energy in Urban Water, Supply Systems. Water, 6 (6), pp. 1546-1561. https://doi.org/10.3390/w6061546

[7] Đurin, B. 2015: Sustainable Water and Energy Use for Irrigation Demands. In WCST-2015 Proceedings, pp. 116-122.

[8] (MHSC), M. and H.S. 2018: Averaged daily flows for river Bednja, measuring station Lepoglava, from 2008. till 2017. 
[9] Sanchez-Miralles, A.; Calvillo, C.; Martin, F.; Villar, J. 2014: Use of Renewable Energy Systems in Smart Cities; Springer, Cham.

[10] Garlik, B. 2019: Optimising Energy Systems in Smart Urban Areas, In Zero and Net Zero Energy, IntechOpen.

[11] Eicker, U. 2019: Urban Energy Systems for Low-Carbon Cities; Eicker, U., Ed., Academic Press.

[12] Miller, P. 2019: Renewable Energy and the Smart City of the Future Available online: https://www.arcweb.com/blog/renewable-energy-smart-city-future Accessed 29 Dec 2019

[13] Prouvoust, B. 2019: Creating the ultimate hybrid system by mixing solar energy and hydroelectricity Available online: http://www.renewableenergyfocus.com/view/45793/creating-the-ultimate-hybrid-system-bymixing-solar-energy-and-hydroelectricity/ Accessed 19 Oct 2019

[14] Rogner, M. 2019: Case study: solar PV-hydro hybrid system at Longyangxia, China Available online: https://www.hydropower.org/blog/case-study-solar-pv-hydro-hybrid-system-at-longyangxia-china Accessed 19 Oct 2019

[15] Muhida, R.; Mostavan, A.; Sujatmiko, W.; Park, M.; Matsuura, K. 2001: The 10 Years operation of a PVmicro-hydro hybrid system in Taratak, Indonesia, Sol. Energy Mater. Sol. Cells, 67 (1-4), pp. 621-627. https://doi.org/10.1016/S0927-0248(00)00334-2

[16] Nfah, E.M.; Ngundam, J.M. 2009: Feasibility of pico-hydro and photovoltaic hybrid power systems for remote villages in Cameroon, Renew. Energy, 34 (6), pp. 1445-1450. https://doi.org/10.1016/i.renene.2008.10.019

[17] Chaurette, J. 2003: Pump System Analysis and Sizing, 5th ed., Fluide Design Inc.

[18] Ebaid, M.S.Y.; Qandil, M.; Hammad, H. 2019: A Unified Approach for a Photovoltaiuc Solar System for the Underground Water Pumping Well-34 at Disi Aquifer, Energy Convers. Manag., 75, pp. 780-795, https://doi.org/10.1016/i.enconman.2013.07.083

[19] Escudero-Pascual, A. 1998: Sizing of standalone PV systems based on the "worst month" method. Man. Energ. Sol. Fotovoltaica y Coop. al Desarro.

[20] Kenna, J.; Gillett, B. 1985: Solar Water Pumping: A Handbook; Intermediate Technology Publications: London, Southampton Row 103/105.

[21] Borisov, B.; Đurin, B.; Matin, J. 2016: The Concept of Sustainable Irrigation on the Example of Football Field of F.C. "'Obreš", Sveti llija, Croatia, Environ. Eng. - Inženjerstvo okoliša, 3 (1), pp. 71-81.

[22] Google Maps Available online: https://www.google.hr/maps/@46.2867434,16.3797178,12.75z?hl=en Accessed on 31 May 2019

[23] PVGIS PVGIS Available online: https://photovoltaic-software.com/pv-softwares-calculators/online-freephotovoltaic-software/pvgis Accessed on 4 Nov 2019

[24] Solarserver Available online: https://www.solarserver.de/ Accessed on 4 Nov 2019

Please cite this article as: Đurin, B.; Kranjčić, N.; Muhar, A.: Smart hydro-energy hybrid system potential in Croatia-Bednja River case study, Electronic Journal of the Faculty of Civil Engineering Osijek-e-GFOS, 2020, 20, pp. 39-50, https://doi.org/10.13167/2020.20.4 